\title{
Kelompok Pendamping Makanan Pendamping Asi (KP-MPASI) di Rumah Sehat Anti Stunting (RS-AS)
}

\author{
Dyah Wiji Puspita Sari ${ }^{1 *}$, Apriliani Yulianti Wuriningsih ${ }^{2}$, Nopi Nur Khasanah ${ }^{3}$ \\ 1,2,3 Fakultas Ilmu Keperawatan Unissula
}

\section{A R T I C L E I N F O}

Article history:

Received 10 December 2019

Received in revised form 01 January 2020

Accepted 30 January 2020

Available online 28

February 2020

\section{Kata Kunci:}

Kader Kesehatan, MPASI

RS-AS

Keywords:

Health Cadres, MPASI, RSAS

\begin{abstract}
A B S T R A K
Fokus Stunting telah menjadi permasalahan gizi serius yang perlu segera ditangani. status gizi balita jawa tengah tahun 2017 pada kategori balita gizi kurang sebanyak $17 \%$, balita pendek sebanyak $28,5 \%$, dan balita kurus sebanyak $9,3 \%$. Metode yang digunakan untuk menjalankan kegiatan ini yaitu metode empowerment. Metode ini dilakukan dalam 4 (empat) tahapan, yaitu (1) sosialisasi, (2) peningkatan kompetensi, (3) pelaksanaan kegiatan, serta (4) monitoring dan evaluasi. Hasil dari pelaksanaan kegiatan ini yaitu KPMPASI memberikan peran yang besar pada pemantauan status gizi ibu hamil dan baduta dalam mencegah resiko stunting. Kesimpulan dalam kegiatan ini yaitu KP-MPASI menjadi strategi yang tepat untuk memberdayakan masyarakat dalam rangka meningkatkan kesiapan anggota keluarga untuk mencegah resiko stunting dan menjadikan KP MPASI ini sebagai salah satu program kesehatan unggulan pencegahan stunting.
\end{abstract}

\section{A B S T R A C T}

The focus of Stunting has become a serious nutritional problem that needs to be addressed immediately. Nutrition status of toddlers in middle of 2017 in the category of undernourished toddlers as much as $17 \%$, short toddlers as much as $28.5 \%$, and thin toddlers as much as $9.3 \%$. The method used to carry out this activity is the empowerment method. This method is carried out in 4 (four) stages, namely (1) socialization, (2) competency enhancement, (3) implementation of activities, and (4) monitoring and evaluation. The results of the implementation of this activity are that the KP-MPASI provides a large role in monitoring the nutritional status of pregnant women and young people in preventing the risk of stunting. The conclusion of this activity is that KP-MPASI is the right strategy to empower the community in order to increase the readiness of family members to prevent the risk of stunting and to make this MPASI KP one of the leading health programs for stunting prevention.

\footnotetext{
* Corresponding author.

E-mail addresses: dyahwiji12@gmail.com (Dyah Wiji Puspita Sari)
} 


\section{Pendahuluan}

Menurut Pusat Data dan Informasi Kementerian Kesehatan RI (2018) angka kejadian stunting di dunia mencapai $23,2 \%$ pada tahun 2015 dan pada tahun 2017 prevalensi stunting mengalami penurunan yang kurang signifikan yaitu hanya $22,2 \%$ setengah dari angka stunting ini, $55 \%$ berasal dari Asia dan sepertiganya berasal dari Afrika 39\%. Terdapat 83,6 juta balita yang mengalami stunting di Asia, proporsi tertinggi terdapat pada Asia selatan yaitu 58,7\% dan proporsi terendah pada Asia tengah 0,9\%. Data tentang jumlah balita pendek dari South East Asian Nutrition Survey (SEANUTS) pada tahun 2010-2011 menempatkan Indonesia sebagai negara yang memiliki jumlah anak balita pendek terbesar, jauh diatas Malaysia, Thailand serta Vietnam (Union, The International, \& Consortium, 2014). Menurut World Assosiation Organization (2018), Indonesia adalah negara yang berasal dari Asia Tenggara, dalam angka kejadian stunting sendiri Indonesia meduduki nomer tiga dengan proporsi tertinggi pada Asia Tenggara yaitu pada tahun 2015-2017 mencapai 36,4\%.

Menurut survey data Pemantauan Status Gizi atau PSG (2018) data yang didapatkan setiap tahun mengalami perubahan yaitu ditahun 2015 angka balita pendek mencapai $29 \%$ dan pada tahun 2016 mengalami penurunan sebanyak 27,5\% akan tetapi menurut survey PSG ditahun 2017 angka kejadian stunting kembali mengalami kenaikan yaitu mencapai 29,6\%. Data dari PSG juga menunjukkan bahwa status gizi balita jawa tengah tahun 2017 pada kategori balita gizi kurang sebanyak 17\%, balita pendek sebanyak $28,5 \%$, dan balita kurus sebanyak 9,3\%.

Negara berkembang seperti Indonesia memiliki masalah yang kompleks, dari mulai angka kemiskinan yang tinggi hingga angka gizi kurang yang tinggi. Menurut Pusat Data dan Informasi Kementerian Kesehatan RI (2018), masalah gizi menjadi salah satu faktor munculnya balita yang mengalami stunting. Hal ini berdampak pada angka kejadian stunting di Indonesia.

Status gizi balita pada hasil utama Riset Kesehatan Dasar (Riskesdas) tahun 2018 menunjukkan bahwa balita yang mengalami gizi kurang dan buruk mencapai angka 17,7\%; sedangkan balita sangat pendek dan pendek mencapai angka 30,8\% (BPPK, 2018). Pada baduta, secara keseluruhan terdapat 18 provinsi dengan prevalensi tinggi $(30 \%-<40 \%)$ yang memiliki masalah status gizi sangat pendek dan pendek, termasuk provinsi Jawa Tengah.

Menurut Setiawan dkk (2018) Masalah kurang gizi dan stunting merupakan dua masalah yang saling berhubungan. Stunting pada anak merupakan dampak dari defisiensi nutrien selama seribu hari pertama kehidupan. Hal ini menimbulkan gangguan perkembangan fisik anak yang irreversible, sehingga menyebabkan penurunan kemampuan kognitif dan motorik serta penurunan performa kerja. Anak stunting memiliki rerata skor Intelligence Quotient (IQ) sebelas poin lebih rendah dibandingkan rerata skor IQ pada anak normal. Gangguan tumbuh kembang pada anak akibat kekurangan gizi bila tidak mendapatkan intervensi sejak dini akan berlanjut hingga dewasa Masalah stunting salah satunya dipengaruhi oleh status gizi ibu dan anak. Status gizi dan kesehatan ibu pada masa pra-hamil, saat kehamilannya dan saat menyusui sejak 1000 hari pertama kehidupan (HPK) merupakan periode sangat kritis. Kekurangan gizi kronik pada 1000 HPK akan berdampak pada gangguan pertumbuhan fisik yaitu salah satunya stunting, hingga berdampak pada kualitas kerja yang tidak kompetitif yang berakibat pada rendahnya tingkat pendapatan dan kesejahteraan masyarakat (Kementerian Koordinator Bidang Kesejahteraan Rakyat, 2013; Trihono et al., 2015). Masalah kekurangan gizi atau stunting disebabkan oleh banyak faktor.

Berbagai bukti ilmiah dari lembaga riset gizi dan kesehatan terbaik di dunia menunjukkan bahwa faktor penyebab terpenting stunting adalah lingkungan hidup sejak konsepsi sampai anak usia 2 tahun yang dapat dirubah dan diperbaiki dengan fokus pada masa 1000 HPK (Barker \& Thornburg, 2013). Bukan karena faktor utama yaitu faktor genetik seperti anggapan masyarakat pada umumnya. Masalah merupakan akibat dari berbagai faktor yang saling terkait. Terdapat dua faktor yang status gizi individu. Salah satu faktor penyebab langsung pertama adalah konsumsi makanan yang tidak memenuhi jumlah dan komposisi zat gizi yang memenuhi syarat gizi seimbang yaitu beragam, sesuai kebutuhan, bersih, dan aman, misalnya bayi tidak memperoleh ASI Eksklusif. (Kementerian Koordinator Bidang Kesejahteraan Rakyat, 2013).

Masalah stunting akan terus terjadi apabila tidak ada perbaikan gizi dan pelayanan kesehatan yang memadai pada masa-masa 1000 HPK. Pentingnya pemenuhan gizi pada kelompok 1000 HPK akan mengurangi jumlah anak pendek di generasi yang akan datang dan seterusnya (Ahmed, Rahman Khan, \& Jackson, 2001; Barker \& Thornburg, 2013; International Food Policy Research Institute, 1999; Kementerian Koordinator Bidang Kesejahteraan Rakyat, 2013).

Asupan gizi anak pada 1000 hari pertama kehidupan (HPK) merupakan salah satu meningkatkan risiko stunting. ASI ekslusif perlu diberikan selama 6 bulan pertama, selanjutnya bayi harus segera mendapatkan MP-ASI agar perkembangan dan pertumbuhan anak optimal. MP-ASI sendiri diberikan 
sesuai dengan frekuensi, tekstur, jumlah, kebersihan, serta keanekaragaman jenis makanan yang juga sesuai untuk anak (Kementrian Kesehatan Gizi Indonesia,2014). Status gizi balita juga perlu diperhatikan lebih oleh orangtua pada periode emas anak. Hal tersebut karena jika cukupan gizi anak kurang akan bersifat irreversible bagi anak (Mufida, Widyaningsih and Maligan 2015).

Menurut penelitian yang dilakukan Noverian dkk (2018) menyebutkan bahwa terdapat hubungan yang signifikan pemberian MP-ASI terhadap stunting.

Salah satu upaya perbaikan dalam menangani masalah stunting adalah melalui pembentukan Rumah Sehat Anti Stunting. Rumah Sehat Anti Stunting berfokus pada pemenuhan gizi dan pembangunan lingkungan yang sadar tumbuh kembang anak pada kelompok 1000 HPK melalui berbagai layanan. Beberapa layanan itu diantaranya adalah pemenuhan gizi pada penyediaan pangan yang bergizi seimbang khususnya bagi ibu hamil dan baduta, pelatihan konsep dan pembuatan makanan pendamping ASI (MPASI) untuk anak usia 6-23 bulan, dan pengelolaan kebun gizi.

Pada program layanannya, RS-AS melibatkan masyarakat baik masyarakat yang terindikasi krisis kesehatan maupun masyarakat yang tidak terindikasi. Salah satu masyarakat yang tidak terindikasi contohnya adalah kader kesehatan (Kemenkes RI, 2018). Kader kesehatan memiliki peran yang besar dalam memfasilitasi masyarakat dalam mencegah stunting. Salah satu peran kader kesehatan Posyandu Balita adalah mendampingi cara pembuatan MP-ASI yang benar pada ibu yang memiliki baduta dan menyediakan makanan bergizi pada baduta saat pelaksanaan posyandu balita.

yang didapat pada studi pendahuluan di Posyandu Manggis, Kelurahan Karangroto didapatkan bahwa dari 38 baduta terdapat 12 bayi (30\%) diantaranya memiliki hasil skor <-2 SD. Sehingga dapat dikatakan bahwa prevelensi anak stunting di Kelurahan Karangroto masih tinggi.

\section{Metode}

Pada pelaksanaan program pengembangan produk intelektual kampus rumah sehat anti stunting ini, TIM RS AS memiliki tanggungjawab sosial atau Corporate Social Responsibility (CSR) untuk menurunkan angka resiko stunting di masyarakat, sehingga TIM RS AS membentuk kelompok pendamping MPASI (KP-MPASI) yang berasal dari kader kesehatan posyandu balita.

Metode pelaksanaan dalam menbentuk KP-MPASI ini dilaksanakan dengan menggunakan metode empowerment. Empowerment merupakan sebuh metode pengabdian masyarakat yang dilakukan dengan memberdayakan masyarakat yang berpotensi untuk melaksanakan tujuan pengabdian masyarakat. Metode ini dilakukan dalam 4 (empat) tahapan, yaitu (1) sosialisasi, (2) peningkatan kompetensi, (3) pelaksanaan kegiatan, serta (4) monitoring dan evaluasi. Penggunaan 4 tahapan ini efektif digunakan untuk memberikan peningkatan pengetahuan dan ketrampilan kader kesehatan dalam kesiapannya melakukan pendampingan kepada ibu hamil dan ibu yang memiliki baduta.

Kegiatan pendampingan yang dilakukan oleh TIM pengabdian ini menjadi cara yang digunakan untuk memberdayakan kader kesehatan posyandu balita dalam memberikan pendampingan dalam pembuatan MP-ASI dan pemberian makanan bergizi pada ibu hamil dan ibu yang memiliki baduta sehingga tujuan dari pengabdian masyarakat tercapai.

Tahapan sosialisasi dilaksanakan untuk memberikan pemahaman mengenai program dan alur serta tahapan program KP-MPASI. Sedangkan pada tahapan peningkatan kompetensi kader kesehatan dilakukan melalui ceramah, curah pendapat, diskusi, dan demo pembuatan MP-ASI.

Pada tahapan pelaksanaan kegiatan tahap pendampingan kader kesehatan, jumlah kader yang terlibat sebanyak 17 orang. Tim pengabdian melakukan pendampingan kepada kader kesehatan dengan mengajarkan cara mengontrol status gizi serta cara pembuatan dan pemberian MPASI yang benar sesuai dengan usia baduta. Setelah proses pendampingan dati tim pengabdian, maka tindak lanjut kader kesehatan mendampingi ibu hamil dan baduta yang beresiko stunting. Harapannya ibu hamil dan baduta yang beresiko stunting yang mendapatkan pendampingan dari kader kesehatan ini akan mencapai kemandirian dalam melakukan pencegahan resiko stunting secara mandiri.

Proses pendampingan yang dilakukan oleh kader kesehatan ke ibu hamil dan baduta yang beresiko stunting dilaksanakan melalui kunjungan rumah atau pada saat pelaksanaan posyandu balita. Pada program pendampingan ini kader kesehatan akan mengontrol status gizi dan mengajarkan cara pembuatan dan pemberian MPASI yang benar sesuai dengan usia baduta.

Pada tahap monitoring dan evaluasi dilaksanakan setiap bulan sekali. Pelaksanaan monev dilaksanakan dengan cara seluruh kader kesehatan dikumpulkan untuk dilakukan monev terhadap pelaksanaan kegiatan selama KP-MPASI berlangsung. Apabila dalam proses pelaksanaan kegiatan ditemukan kendala oleh para kader, tim pengabdian memberikan pembinaan dan penguatan terhadap masalah yang ditemukan. 
Pelaksanaan kegiatan ini dilaksanakan di beberapa posyandu wilayah binaan puskesmas Bangetayu Kota Semarang dari bulan Maret hingga Oktober 2019. Teknik pengumpulan data dilakukan dengan menggunakan kuesioner dan lembar observasi. Teknik analisa data yang digunakan dalam plaksanaan kegiatan pengabdian masyarakat ini adalah distribusi frekuensi.

\section{Hasil dan Pembahasan}

Pelaksanaan kegiatan pengabdian masyarakat pada pembentukan KP-MPASI telah dilaksanakan melalui tahapan sosialisasi, peningkatan kompetensi, pelaksanaan kegiatan, serta monitoring dan evaluasi. Melalui tahapan sosialisasi memberikan hasil bahwa kader kesehatan memahami, mempunyai pola fikir dan mempunyai komitmen pada perannya dalam menurunkan resiko stunting di masyarakat yang salah satunya melalui pendampingan pembuatan MP-ASI. Pembuatan dan cara pemberian yang benar pada MPASI memberikan peran yang besar dalam memperbaiki masalah ancaman gizi pada bayi usia dua tahun.

Hasil penelitian Imtihanatun dkk (2013) menyebutkan bahwa bayi dibawah dua tahun (Baduta) dan bayi dibawah 3 tiga tahun (Balita) yang mendapatkan MPASI tidak sesuai memiliki risiko 7,4 kali mengalami stunting dibandingkan dengan baduta dan balita yang mendapatkan MPASI sesuai. Hal ini menunjukkan bahwa pemahaman tentang MPASI perlu di sosialisasikan secara benar ke masyarakat.

Kegiatan sosialisasi ini menjadi tahapan yang sangat penting untuk memberikan pemahaman kepada kader tentang arti pentingnya MP ASI dalam menurunkan resiko stunting di masyarakat.

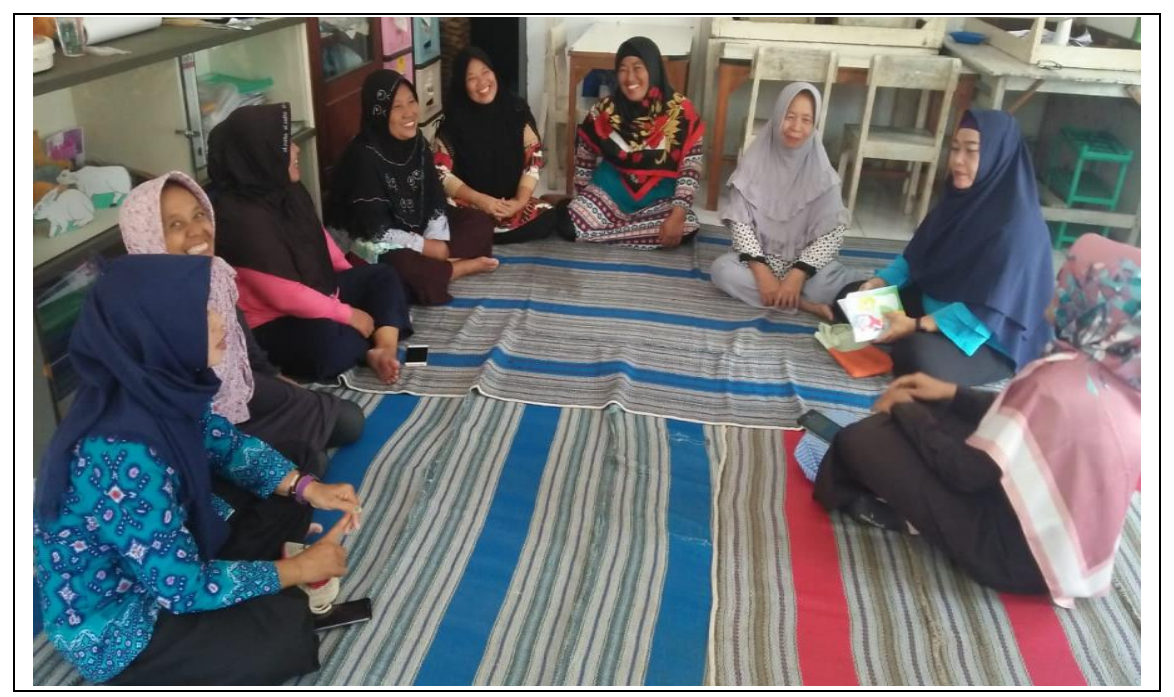

Gambar 1. Pelaksanaan Sosialisasi

Pada metode peningkatan kompetensi, sebelumnya kader kesehatan di berikan pre test tentang segala hal yang berkaitan dengan stunting dan MP ASI seperti cara melakukan skining pada ibu hamil dan baduta yang beresiko stunting, cara membuat MPASI, frekuensi pemberian, kandungan gizi, menu 4 bintang, cara penyajian MPASI, dan lain sebagainya. kemudian dilanjutkan dengan pemberian materi dan demo masak cara pembuatan MPASI sesuai umur. Setelah pemberian materi maka kegiatan ini diakhiri dengan post test.

Dengan adanya pre test diharapkan menjadi tolok ukur untuk melihat kemampuan awal kader kesehatan untuk melakukan skrining ibu hamil dan baduta yang beresiko stunting serta melihat pemahamannya tentang MPASI. Hasil pre test menunjukkan hampir seluruh kader kesehatan belum memahami secara benar tentang MPASI. Setelah dilaksanakan proses pendampingan oleh TIM Rumah Sehat Anti Stunting maka kemampuan kader kesehatan tentang MPASI mengalami peningkatan yang signifikan. Seluruh kegiatan pendampingan ini dilakukan dengan metode pelatihan, role play, pemberian pendidikan kesehatan, penyuluhan dan kunjungan ke kebun gizi. 


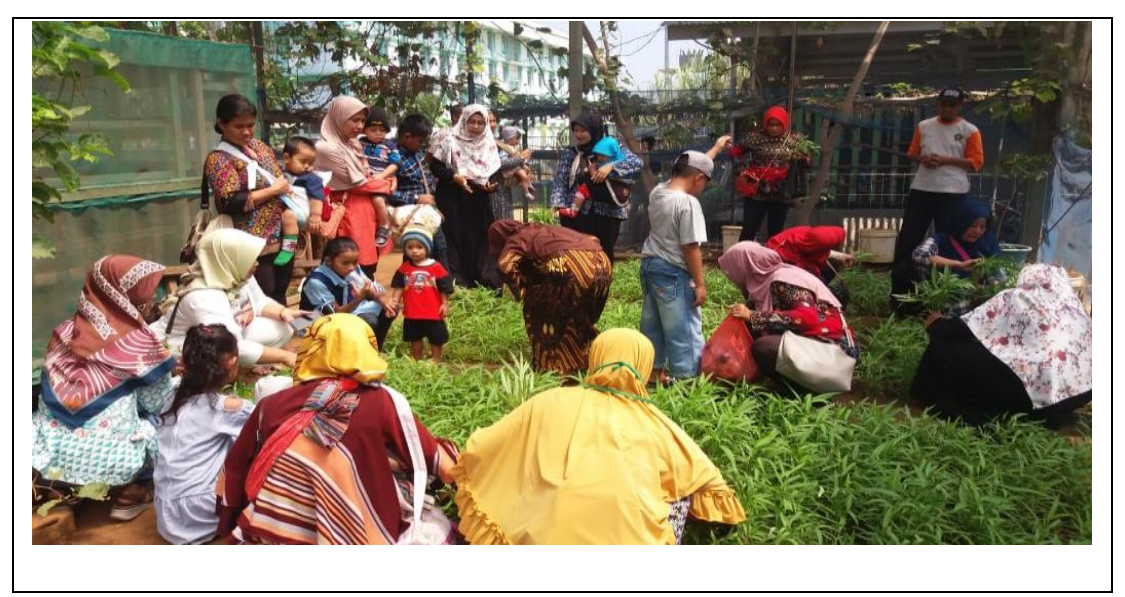

Gambar 2. Kunjungan ke kebun gizi

Kebun Gizi merupakan salah satu fasilitas yang disediakan oleh rumah sehat anti stunting dalam perannya untuk memberikan pemenuhan nutrisi organik pada ibu hamil dan baduta yang beresiko stunting. Pada kebun gizi meyediakan sumber nutrisi organik yang terdiri dari sayuran, buah, kolam ikan, dan kandang unggas yang diharapkan mampu mensupport kebutuhan pemberian MPASI khususnya pada sumber vitamin dan protein. Pada kebun gizi ini warga di beri kesempatan untuk memetik sayuran organik sendiri sebagai bahan pembutan MPASI.

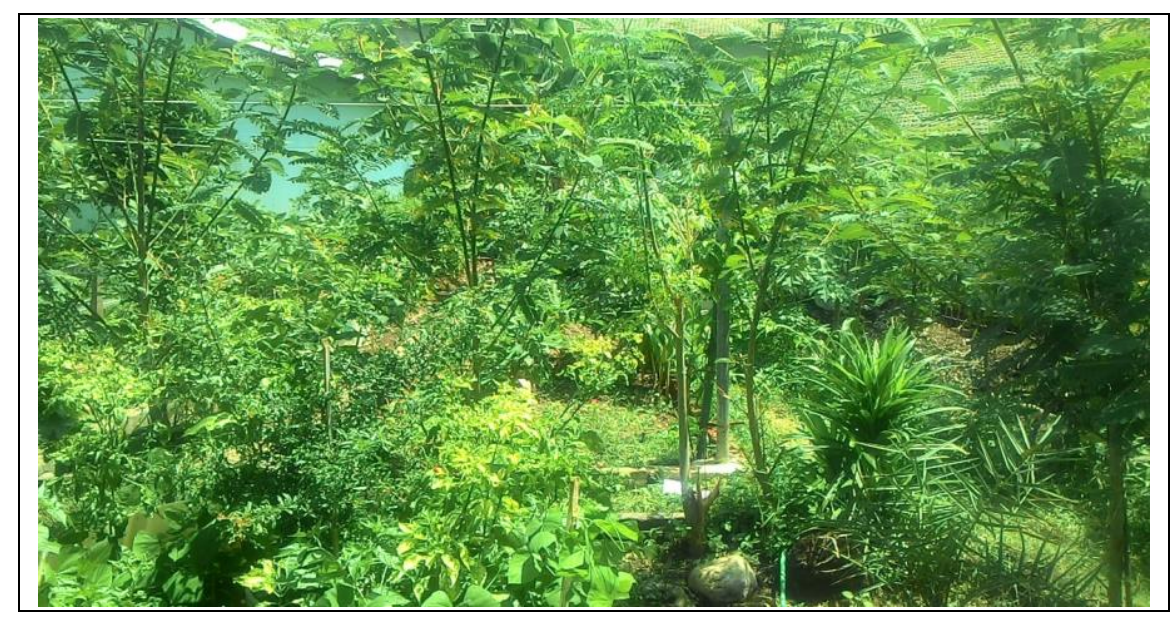

Gambar 3. Kebun Gizi

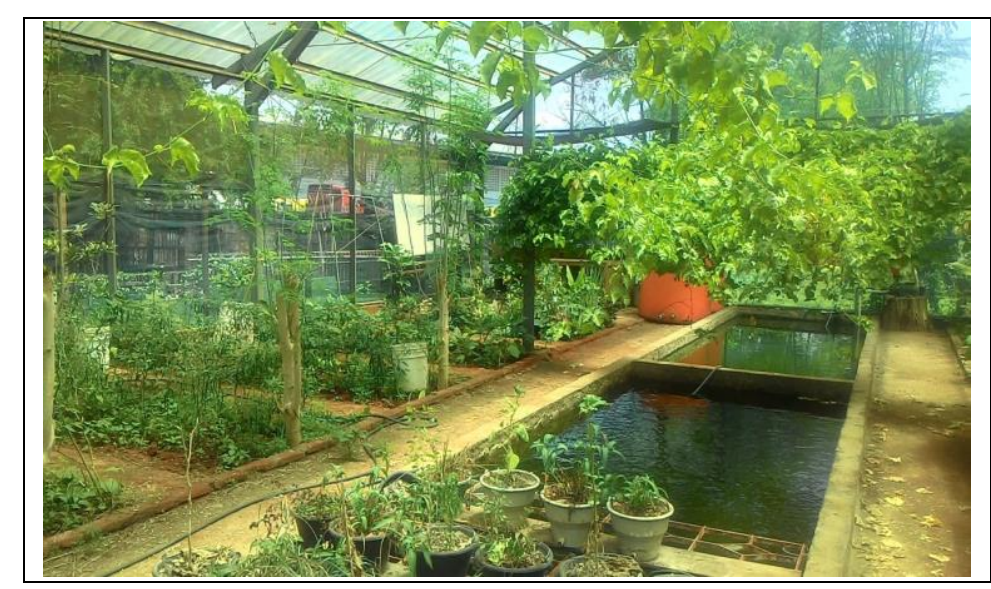

Gambar 4. Kolam ikan 
Cushway (2001) menyebutkan bahwa pelatihan bertujuan untuk memengembangkan keahlian dan dan kemampuan individu untuk memperbaiki kinerja, membiasakan pegawai dengan sistim, prosedur dan metode kerja yang baru, serta membantu pegawai dan pendatang baru menjadi terbiasa dengan persyaratan pekerjaan tertentu dan persyaratan organisasi. Hasil penelitian Dahmiri \& Sakta (2014) menunjukkan bahwa pelatihan memberikan kontribusi terhadap kinerja pegawai Dinas Pendidikan Kabupaten Sarolangun dengan angka koefisien determinasi $r$ square sebesar 0,253 yang berarti 25,3\% perubahan pada variabel kinerja Pegawai (Y) dapat diterangkan oleh pengaruh pelatihan (X).

Pemberian pendidikan kesehatan dan penyuluhan pada hakikatnya merupakan suatu kegiatan untuk menyampaikan pesan kepada masyarakat, kelompok, atau individu dengan harapan kelompok tersebut mendapatkan pengetahuan tentang kesehatn yang lebih baik. Hal ini seirama dengan pendapat Notoadmodjo (2005) yang menyatakan bahwa informasi akan berpengaruh terhadap pengetahuan seseorang. Pada kegiatan pendidikan kesehatan dan penyuluhan ini TIM pengabdi menggunakan berbagai media diantaranya power point, modul, dan aplikasi skrining stunting berbasis android.

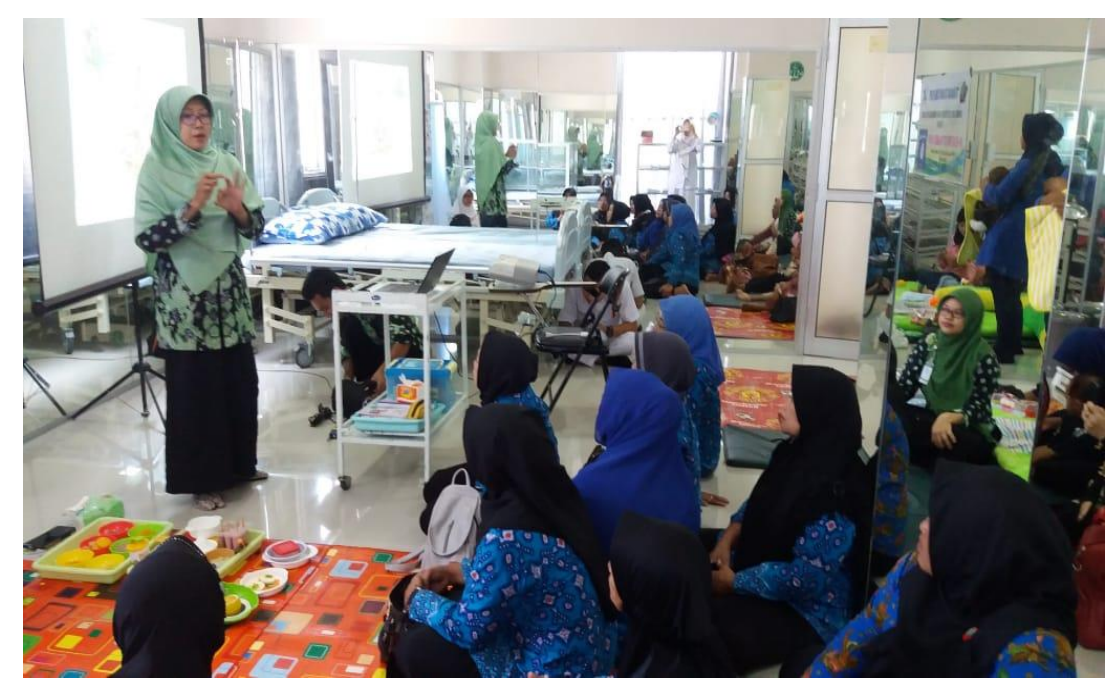

Gambar 5. Pendampingan Pada Kader Kesehatan

Setelah di berikan pendampingan tentang MP ASI maka selanjutnya kader kesehatan akan mendampingi warga masyarakat yang beresiko stunting untuk membuat MPASI yang benar. Serta memasukkan prinsip pembuatan MPASI dalam memberikan makanan tambahan pada saat dilaksanakannya posyandu balita.

Pada tahapan monitoring dan evaluasi dilaksanakan setiap bulan sekali dengan cara seluruh kader kesehatan dikumpulkan untuk dilakukan monitor dan evaluasi terhadap pelaksanaan kegiatan selama KP MPASI berlangsung. Monitoring dan evaluasi merupakan sebuah proses yang berkesinambungan meliputi pengumpulan data, proses dan pemilihan informasi mengenai implementasi proyek, progress yang dicapai pada proyek tersebut sampai kepada dampak dan efek dari adanya proyek tersebut (Ojha, 1998). Hasil riset yang dilakukan oleh Muktiali (2009) menunjukkan bahwa kegiatan monitoring dan evaluasi diperlukan untuk melihat tingkat keberhasilan dan ketercapaian tujuan dan manfaat program-program pembangunan Kota Semarang. 


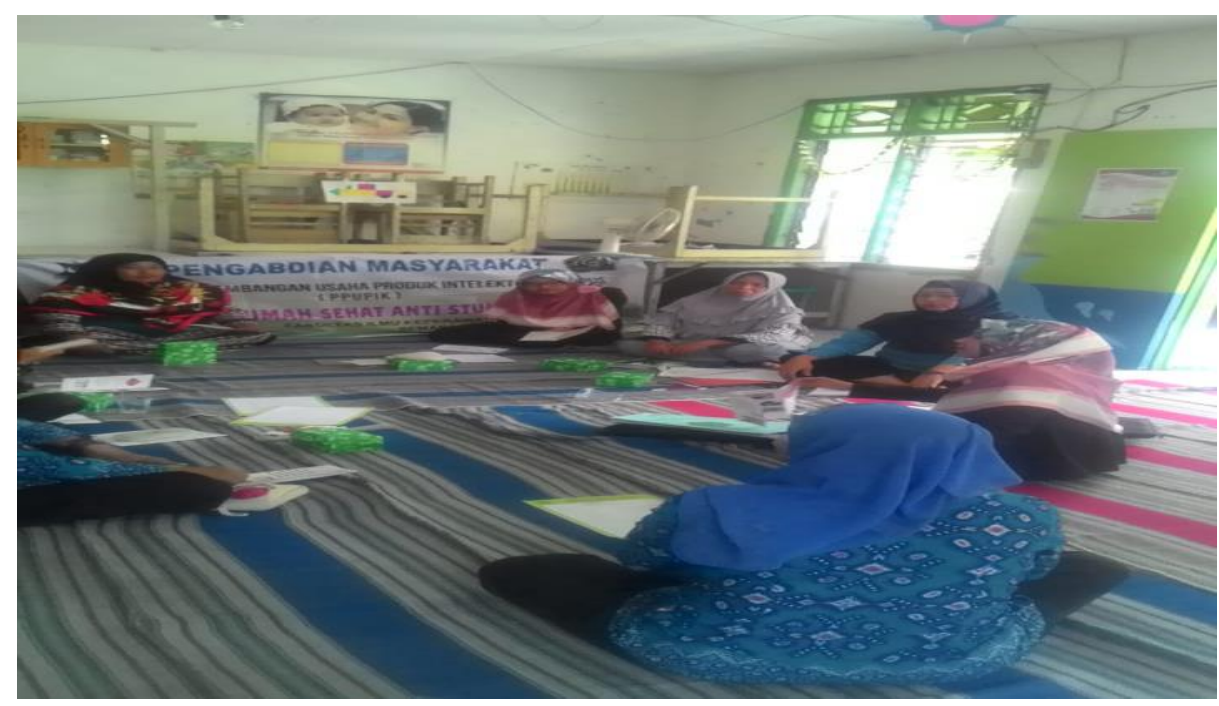

Gambar 6. Hasil Monitoring

Berdasarkan hasil monitoring evaluasi juga didapatkan peningkatan yang signifikan pada kualitas dan keanekaragaman pemberian MPASI pada ibu yang memiliki baduta serta pada pemberian makanan tambahan yang diberikan kader pada saat pelaksanaan posyandu balita. Hal ini menunjukkan bahwa KPMPASI memiliki peran yang cukup signifikan dalam meningkatkan kualitas hidup diabetisi.

Keunggulan Program Pengabdian Masyarakat KP-MPASI yaitu menjadi strategi yang efektif dan terintegrasi, berbasis masyarakat melalui kerjasama lintas program dan lintas sektor untuk menurunkan resiko stunting melalui pemenuhan gizi dengan pemahaman, pembuatan dan pemberian MPASI yang benar. Pada Pelaksanaan kegiatan pengabdian ini tidak dialami kesulitan yang signifikan karena kader kesehatan mampu bekerjasama dengan sangat baik.

\section{Simpulan dan Saran}

Pengabdian masyarakat pembentukan Kelompok Pendamping Makanan Pendamping ASI (KPMPASI) dapat disimpulkan bahwa terbentuknya KP-MPASI memberikan peran yang besar pada pemantauan status gizi ibu hamil dan baduta dalam mencegah resiko stunting serta menjadi strategi yang tepat untuk memberdayakan masyarakat dalam rangka meningkatkan kesiapan anggota keluarga untuk mencegah resiko stunting. Rekomendasi untuk kegiatan pengabdian masyarakat selanjutnya adalah mengembangakan KP-MPASI di seluruh kader kesehatan posyandu balita.Program kegiatan KP-MPASI ini masih berada dalam lingkup yang kecil tetapi telah memberikan dampak yang cukup baik dalam menurunkan resiko stunting, sehingga diharapkan menjadi inisiasi awal bagi pemangku kebijakan untuk menjadikan KP MPASI ini sebagai salah satu program kesehatan unggulan pencegahan stunting.

\section{Daftar Rujukan}

Adriana, D., 2011. Tumbuh Kembang dan Therapy Bermain pada anak. Jakarta: Salemba Medika

Ahmed, F., Rahman Khan, M. and Jackson, A. A., 2001. 'Concomitant supplemental vitamin A enhances the response to weekly supplemental iron and folic acid in anemic teenagers in urban Bangladesh', American Journal of Clinical Nutrition, 74(1), pp. 108-115. 2.

Aridiyah, F. O., Rohmawati, N., \& Ririanty, M., 2015. Faktor-faktor yang mempengaruhi kejadian stunting pada anak balita di wilayah pedesaan dan perkotaan. Pustaka Kesehatan, 3(1), 163-170.

Astuti, D. K., 2016. Hubungan karakteristik ibu dan pola asuh gizi dengan kejadian balita (Universitas Muhammadiyah Surakarta). Retrieved from http://eprints.ums.ac.id/42620/ 
Barker, D. J. P. and Thornburg, K. L. (2013) 'Placental programming of chronic diseases, cancer and lifespan: A review', Placenta. Elsevier Ltd, 34(10), pp. 841-845. doi: 10.1016/j.placenta.2013.07.063.

BPPK. 2018. Hasil utama riskesdas 2018. Jakarta.

Engebretsen, I., M., S., Jackson, D., Fadnes, L., T., Nankabirwa, V., Diallo, A., H., \& Nankunda, J., 2014. Growth effects of exclusive breastfeeding promotion by peer counsellors in sub-Saharan Africa: the clusterrandomised PROMISE EBF trial. BMC Public Health, 14:633. Retrieved from: http://www.biomedcentral.com/1471-2458/14/633

Imtihanatun, N., 2013. Faktor risiko balita stunting usia 12-36 bulan di Puskesmas Dasan Agung, Mataram, Provinsi Nusa Tenggara Barat. Public Health and Preventive Medicine Archive, 1(1).

International Food Policy Research Institute., 1999. 'Eradicating Malnutrition: Income Growth or Nutrition Programs?' Available at: http://ebrary.ifpri.org/cdm/ref/collection/p15738coll2/id/125333. 3.

Kementrian Kesehatan RI (2016b) 'Situasi balita pendek', Info Datin, pp. 2442-7659. doi: ISSN 2442-7659.

Kemenkes, 2014. 'Pedoman Gizi Seimbang', Riskesdas, p. 99. 4.

Kemenkes, 2014. 'PMK No. 88 Tablet Tambah Darah', Kemenkes 2014, (1), pp. 1-5. doi: 10.1007/s13398014-0173-7.2. 5 .

Kementerian Koordinator Bidang Kesejahteraan Rakyat (2013) 'Kerangka Kebijakan Gerakan Nasional Percepatan Perbaikan Gizi dalam Rangka Seribu Hari Pertama Kehidupan (Gerakan 1000 HPK)', p. 71.

Mufida, L., Widyaningsih, T. D., \& Maligan, J. M., 2015. Prinsip Dasar MPASI Untuk Bayi Usia 6-24 Bulan: Kajian Pustaka. Jurnal Pangan dan Agroindustri Vol. 3 No 4 p.1646-1651

Nova, M. \& Afriyanti, O., 2018. Hubungan bert badan, ASI eksklusif, MP-ASI dan asupan energi dengan stunting pada balita usia 24-59 bulan di Puskesmas Lubuk Buaya. Jurnal Kesehatan Perintis, Vol $5(1)$.

Profil Kesehatan Kota Semarang., 2016. Diakses dari http://depkes.go.id

Profil Kesehatan Provinsi Jawa Tengah., 2016. Diakses dari http://depkes.go.id

Riskesdas, 2013. Laporan Nasional 2013. Departemen Kesehatan Republik Indonesia, Jakarta: Badan Penelitian dan Pengembangan Kesehatan

Robert, I., Coppieters, Y., Swennen, B., \& Dramaix, M., 2014. Breastfeeding Duration: A Survival AnalysisData from a Regional Immunization Survey. BioMed Research International, Volume 2014, Article ID 529790, 8 pages. Retrieved from: http://dx.doi.org/10.1155/2014/529790

Setiawan, eko, Rizanda Machmud, Masrul. 2018. Faktor-Faktor yang Berhubungan dengan Kejadian Stunting pada Anak Usia 24-59 Bulan di Wilayah Kerja Puskesmas Andalas Kecamatan Padang Timur Kota Padang Tahun 2018. Jurnal Kesehatan Andalas. Vol. 7 No. 2 Hal. 275-284. Tersedia Pada: http://jurnal.fk.unand.ac.id/.

Sulistyawati, A., 2014. Deteksi Tumbuh Kembang Anak. Jakarta: Salemba Medika

WHO. 2010. Nutrition Landscape Information System (NLIS): Country Profile Indicators. Switzerland: WHO

WHO. 2018. WHA Global Nutrion Targets 2025 : Stunting Policy Brief. WHO Press: Geneva 